\title{
Crag-and-tail features on the Amundsen Sea continental shelf, West Antarctica
}

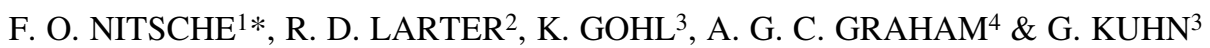 \\ ${ }^{1}$ Lamont-Doherty Earth Observatory, Columbia University, Palisades, New York 10964, USA \\ ${ }^{2}$ British Antarctic Survey, Natural Environment Research Council, High Cross, Madingley Road, Cambridge CB3 OET, UK \\ ${ }^{3}$ Alfred Wegener Institute, Helmholtz Centre for Polar and Marine Research, Am Alten Hafen 26, D-27568 Bremerhaven, Germany \\ ${ }^{4}$ College of Life and Environmental Sciences, University of Exeter, Rennes Drive, Exeter EX4 4RJ, UK
}

*Corresponding author (e-mail: fnitsche@ldeo.columbia.edu)

\begin{abstract}
On parts of glaciated continental margins, especially the inner shelves around Antarctica, grounded ice has removed pre-existing sedimentary cover, leaving subglacial bedforms on eroded substrates (Anderson et al. 2001; Wellner et al. 2001). While the dominant subglacial bedforms often follow a distinct, relatively uniform pattern that can be related to overall trends in palaeoice flow and substrate geology (Wellner et al. 2006), others are more randomly distributed and may reflect local substrate variations. Here we describe and discuss examples of large, isolated crag-and-tail features that are recognized on the Amundsen Sea continental shelf.
\end{abstract}

\section{Description}

The trough in front of Getz Ice Shelf which was generated by palaeo-ice streams, is floored by exposed bedrock (Nitsche et al. 2007; Larter et al. 2009). Geomorphological features preserved at the seabed include bedrock channels, grooves and drumlinshaped landforms (Fig. 1a). In between these features are prominent, shallower mounds (white arrows in Fig. 1a) that rise several tens to hundreds of metres above the surrounding seafloor. Their dimensions range from a few hundred metres to $5-6 \mathrm{~km}$ with length-to-width ratios between 1 and 5. Although these features are slightly streamlined in the direction of the palaeo-ice flow, their lower length-to-width ratio makes them distinct from more elongate surrounding drumlin-shaped bedforms. Typical profiles in the direction of inferred palaeo-ice flow reveal steep fronts up-ice, with a more gently sloping, tail-like end that tapers away downstream (Fig. 1d). Sub-bottom profiles show no indication of soft sediment cover. The larger of these features consist of several smaller streamlined ridges in their tail sections with heights of tens of metres and lengths of up to a few kilometres (Fig. 1b, c).

\section{Interpretation}

The overall elongated shape of the shallow streamlined bedforms, combined with the fact that these bedforms are embedded in a field of other elongated features with a clear subglacial genesis, indicates that they were formed by erosion beneath flowing ice. The irregular spacing of these bedforms, their grouping into bands and their variations in width and length indicate that bedrock composition is likely to be a controlling factor in their distribution and form. Similar features in glaciated terrestrial landscapes are considered to be more resistant bedrock obstacles that have withstood erosion compared to that of the surrounding, weaker substrates (Glasser \& Bennett 2004). We interpret these features as crag-and-tails.

Focused erosion on the stoss side of bedrock knobs or 'crags' leads to the characteristic steep slope facing up-ice. Cavities that form at the lee side of the bedrock protrusions shelter pre-existing weaker material from ice erosion and/or allow for fresh deposition of unconsolidated material, such as till, downflow. The weaker downstream 'tail' is gradually streamlined by overriding ice which leads to its characteristic tapering and allows formation of the secondary features. Multiple, elongated ridges in the tail could be related to the unevenness of the top of the 'crags'. Secondary, smaller crag-and-tail features might reflect variations in the underlying substrate or ice-flow dynamics.

While the length-to-width ratio of crag-and-tail features in this case is much lower than for drumlins or elongate lineations, the boundary between feature classes is indistinct. Crag features with long tails might have geometries that resemble the classical shape of drumlins, while features sometimes described as 'rock drumlins' can, conversely, mirror the geometries of crag-and-tail bedforms. Glaciologically, however, the presence of crag-and-tails implies formation beneath warm-based ice, consistent with the interpretations of palaeo-ice streams in the Getz Trough (Graham et al. 2009).

Details of the rock types of the individual features described here are currently unknown. The few existing seismic lines from the continental shelf of the Amundsen Sea do not allow for individual bedrock units to be resolved (Larter et al. 2007). However, a number of the crag-and-tails found outside the Getz Ice Shelf appear to be grouped in poorly defined, east-west bands, perhaps indicating that they are associated with intrusions of harder lithologies related to the tectonic history of the area (Gohl 2012).

\section{References}

Anderson, J.B., Smith Wellner, J., Lowe, A.L., Mosola, A.B. \& SHIPP, S. 2001. Footprint of the expanded West Antarctic ice sheet: ice stream history and behavior. GSA Today, 11, 4-9.

Glasser, N.F. \& BennetT, M.R. 2004 Glacial erosional landforms: origins and significance for palaeoglaciology. Progress in Physical Geography, 28, 43-75.

GoHL, K. 2012. Basement control on past ice sheet dynamics in the Amundsen Sea Embayment, West Antarctica. Palaeogeography, Palaeoclimatology, Palaeoecology, 335-336, 35-41.

Graham, A.G.C., Larter, R.D., Gohl, K., Hillenbrand, C.-D., SMith, J.A. \& KunN, G. 2009. Bedform signature of a West Antarctic palaeo-ice stream reveals a multi-temporal record of flow and substrate control. Quaternary Science Reviews, 28, 2774-2793.

Larter, R.D., Gohl, K. ex aL. 2007. West Antarctic Ice Sheet change since the Last Glacial Period. Eos Transactions, AGU, 88, 189-196.

LARTER, R.D., Graham, A.G.C. ET AL. 2009. Subglacial bedforms reveal complex basal regime in a zone of paleo-ice stream convergence, Amundsen Sea embayment, West Antarctica. Geology, 37, 411-414.

Nitsche, F.O., JACOBS, S., LarTer, R.D. \& Gohl, K. 2007. Bathymetry of the Amundsen Sea continental shelf: implications for geology, oceanography, and glaciology. Geochemistry, Geophysics, Geosystems, 8, Q10009.

Wellner, J.S., Lowe, A.L., ShipP, S.S. \& ANDERson, J.B. 2001. Distribution of glacial geomorphic features on the Antarctic continental shelf and correlation with substrate: implications for ice behaviour. Journal of Glaciology, 47, 397-411.

Wellner, J.S., Heroy, D.C. \& ANDERSon, J.B. 2006. The death mask of the Antarctic ice sheet: comparison of glacial geomorphic features across the continental shelf. Geomorphology, 75, 157-171. 


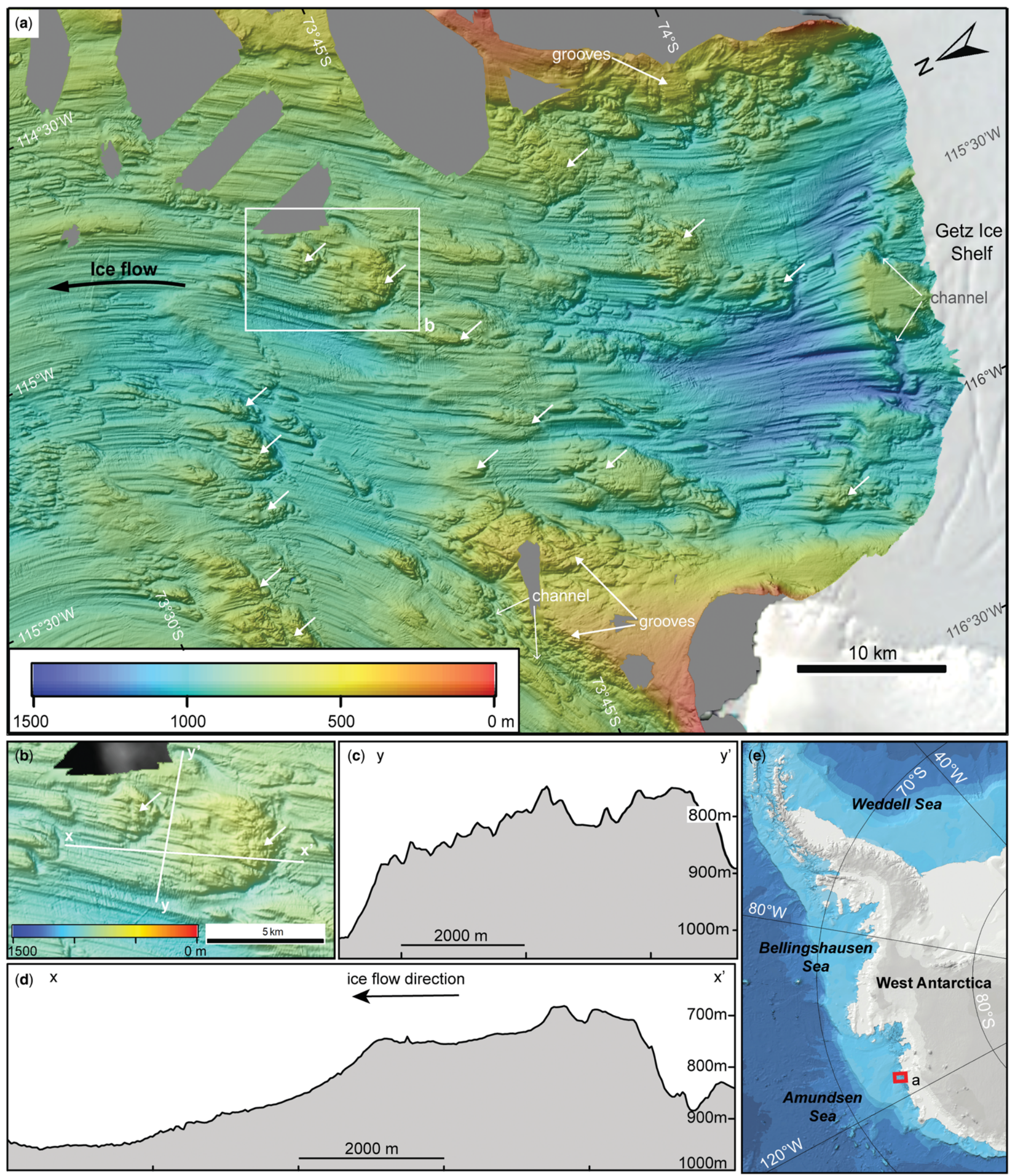

Fig. 1. Multibeam bathymetry and cross-profiles of erosional glacial features on the inner continental shelf of the Amundsen Sea, West Antarctica. (a)

Sun-illuminated multibeam-bathymetric image of the Getz cross-shelf trough showing various glacial landforms including three east-west orientated bands of crag-and-tail features (marked by white arrows). Acquisition systems Kongsberg EM120 and Hydrosweep DS2. Frequency 12 kHz. Grid-cell size 35 m. (b) Detailed view of crag-and-tail features with secondary features. White lines mark profile locations. (c) Profile perpendicular to palaeo-ice flow (VE $\times 9)$. (d) Profile parallel to palaeo-ice flow. Note the steeper side facing the present ice sheet $(\mathrm{VE} \times 7)$. (e) Location of the study area (red box; map from IBCSO v. 1.0). 